\title{
Evaluation of Disleksia Belajar Mobile App for Assisting Dyslexic Junior School Students to Learn the Malay Language
}

\author{
Novia Admodisastro ${ }^{1}$, Chan Kai Fung ${ }^{2}$, Siti Suhaila Abdul Hamid ${ }^{3}$ \\ ${ }^{1,2,3}$ Faculty of Computer Science \& Information Technology, Universiti Putra Malaysia, 43400 UPM Serdang \\ Selangor, Malaysia \\ novia@upm.edu.my ${ }^{1}$, asterckf@gmail.com², gs42041@ student.upm.edu.my ${ }^{3}$
}

Article History: Received: 10 November 2020; Revised: 12 January 2021; Accepted: 27 January 2021; Published online: 05 April 2021 Abstract: Mobile apps are fast emerging as assistive learning platforms for pre-schoolers, as well as junior school students.
In fact, not just the parents but also the junior-level teachers encourage children to use mobile learning apps due to its many
benefits such as interactive, enjoyable and informal, etc. Needless to say, the advent of mobile apps must also equitable for
students with learning difficulties to take advantage of the same learning opportunities as other students. Students with
learning difficulties suffer from disabilities in language, information processing, etc. that prevent them from performing their
academic tasks in the same manner as other students. It is crucial to realize the development of mobile learning apps for
students with learning difficulties requires inclusive designs that make the apps usable for them. The paper presents an
evaluation of a mobile appDisleksia Belajar, which developed for students with dyslexia in junior school to learn the Malay
language. Dyslexia is a common learning difficulty that causes problems with language processing e.g. reading and writing.
The evaluation is performed using SUS and Fun ToolKit (v3) techniques, which intend to explore the usability and
engagement of the mobile app. There is a total of 12 students with dyslexia aged 7 to 12 years old recruited as the
participants. The findings contribute towards understanding and improvement for the future development of mobile learning
apps for students that having similar difficulty.

Keywords:Usability, Engagement, Mobile App, Dyslexia, Children,Fun Toolkit.

\section{Introduction}

Dyslexia is defined as a specific learning difficulty (SpLD) that affects skills related to language (Lyon et al., 2003). A staggering 5-10\% of the world population experience dyslexia, which equates to around 700 million people worldwide (Dyslexia International, 2017) that makes an individual difficult to read, write, and spell, no matter how intelligent he or she is. Besides affecting cognitive skills, dyslexics are also facing behavioural issues such as frustration, emotional distress, and low self-confidence (Alden \& Pollock, 2011). Early intervention is vital to successfully help dyslexics overcome their learning challenges and junior school is an important phase to mastery language skills. Nevertheless, teaching dyslexics is a complex, challenging, and demanding task (Ndombo et. al., 2013). It requires learning styles that promote a higher degree of visual, auditory, and kinesthetics sensory. Also, dyslexics students in rural and remote regions are reported to have limited access to educational resources and services (Ahmad \&Mutalib, 2015; Alias \& Dahlan, 2015). In a traditional classroom context, dyslexics students across different needs and difficulties rely heavily on a teacher (Hoien\& Lundberg, 2000) and limitation of the student-to-teacher ratio makes attention to an individual student more challenging (Ministry of Education, 2018).

Mobile learning apps are fast emerging as supplementary, assistive, and accessible learning platforms for preschoolers as well as junior school students. Mobile apps promote a multi-sensory approach that enriches with multimedia elements. In this context, mobile apps may become indispensable as a learning platform for students with special educational needs and dyslexic in particular (Madeira, 2015). It is crucial to adopt inclusive design in the development of software learning apps for students with dyslexia in which the apps will become closely aligned to their needs (Nganji\&Nggada, 2011). For example, Madeira (2015) highlighted dyslexia-friendly font style, formatting, writing, and layout on app learning materials. This leads to more usable learning apps for students. There are three main works developed to learn the Malay language for students with dyslexia in junior school. First, Cara Interaktif TulisAbjad (CInTA) is a mobile app developed for students with dyslexia to learn the alphabet and writing (Rahim et. al., 2018). The work is still at the preliminary stage of gathering feedback from several experts through interview sessions. Second, Dyslexia Baca is a mobile app to help recognise and distinguish confusing letters such as P, p, b, d, m, and w (Daud \& Abas, 2013). The app employed the phonic reading technique and multisensory approach blended with interactive multimedia, which incorporates text, graphics, video, and animation. The researcher has conducted a heuristic evaluation with seven multimedia experts to evaluate the work. Finally, BacaMAX developed to ease reading and text processing by allowing the students to customise background colour, syllable colour, and font size based on preferences (Husni and 
Jamaludin, 2015). The app employed reading by colours through the Irlen method. So far, the work only covers the experimentation of colours in promoting student attention.

Tommy et. al. (2019) and ChePa et al. (2019) suggested in addition to usability, behaviour factors such as fun and engagement important to be assessed, particularly in learning apps for children. In his work, the fun and engagement are measured using the Adaptive Behaviour Scale and Again-Again Table. In the latest version of Fun ToolKit (v3) introduced by Read (2008), the author also explores the fit between the toolkit, and usability and engagement. Thus, in this paper, we present an evaluation study of Disleksia Belajar using the techniques defined in Read (2008). The remainder of the paper is organised as follows; Section 2 introduces the Disleksia Belajar mobile app, and in Section 3, the paper discusses the methodology. Section 4 presents the evaluation of Disleksia Belajar follows with Section 5 described the evaluation results. Finally, the paper provides concluding remarks.

\section{The Disleksia Belajar Mobile App}

Disleksia Belajar is a mobile app developed for students with dyslexia in junior school to learn the Malay language (Admodisastro et al., 2018). The development of the app strives for inclusive design by utilising font, colour, feedback, and learning contents that are considered dyslexia-friendly. Also, it has an interactive user interface and integrated with various multimodality (audio, text, image). The mobile app was implemented on Android. This choice was based on the fact that most students have a mobile device equipped with this operating system. Based on GlobalStats (2020) the Android is holding $78 \%$ of the mobile operating system market share in Malaysia. The app covers basic topics to learn the Malay language which includes phonology, spelling, reading, and writing (refer Fig. 1). For example, the phonology module highlights the alphabet, vowels, and consonant recognition. In order to make the students interact with the app, this module tests the student's memorisation of confused alphabets with mind test. Module spelling on the other hand, evaluates the student's spelling skill particularly the combination of consonants (C) and vowels (V). The module assesses syllables knowledge such as $\mathrm{CVC}, \mathrm{CV}+\mathrm{CVC}, \mathrm{CV}+\mathrm{CV}+\mathrm{CVC}$, digraph, and diphthong. While module reading focuses on the vocabulary where the students need to read and match the word with given pictures. Finally, the writing module, which concentrates on copying skill and comprehension skills by filling in the blanks with correct words.

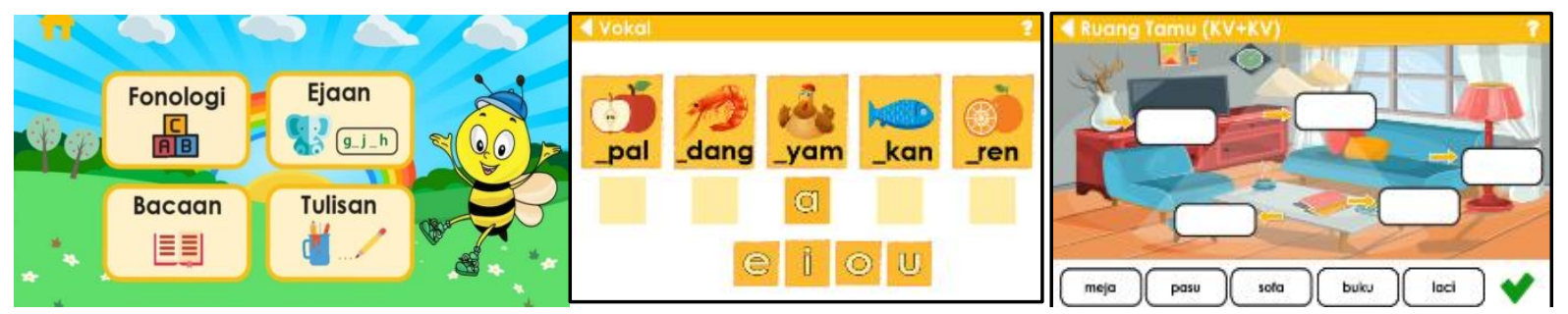

Figure 1.Modules in Disleksia Belajar

\section{Methodology}

The evaluation is conducted with the main objective is to explore the usability and engagement of Disleksia Belajar mobile app. The usability refers to what extent the mobile app can be used by the students to achieve a specific goal related to effectiveness, efficiency, and satisfaction (Kaya et al., 2019) and (Hussain et al., 2020). While engagement refers to how a student shares a positive connection to peers or activities. The checklists include Software Usability Study (SUS) and FunToolkit (v3) defined in Read (2008). The FunToolkit has two tools i.e. the Smileyometer and the Again-again Table. In addition, we are using the observation method to observes the general behaviour of the students while using the mobile app. The observation approach that we have used is a semi-structured observation that consists of a checklist as a guide and we also watch and capture any emerging behaviours. However, due to page limitations, the observation results are not presented in this paper. Prior to the study, ethical clearance from the Ethics Committee Research Involving Human Subjects (JKEUPM) and parents' consents were obtained.

\subsection{Software Usability Study (SUS)}

Positive SUS questionnaire introduced by Sauro\& Lewis (2011) is used in this study. The positive SUS helps to reduce misinterpretation, mistake, and miscode among students with dyslexia when using a common SUS that alternate the questions between positive and negative sentences (Sauro\& Lewis, 2011). Similar to common SUS, the positive SUS questionnaire also contains 10 questions of usability (refer Table 1). The questionnaire is translated into a simple Malay language for the student's understanding without altering the connotation. A 
facilitator is assigned to help reading the questions to the students. The reason is that some of the students are still not able to read fluently which therefore makes it difficult for them to answer the questionnaire.

In addition, Smileyometer is adopted to replace the Likert scale. The Smileyometer, as illustrated in Fig. 2, is based on a 5-point Likert scale that uses five smiley faces with supporting words above the faces. It is used to elicit the student's answers by asking them to tick one face. According to Read (2008), the use of a smiley icon can ease the student in making the decision.

Table 1.The 10-questions for System Usability Scale (SUS)

\begin{tabular}{|l|l|}
\hline SUS Positive Questions (in Malay language) \\
\hline $\mathbf{1}$ & Saya akansentiasa menggunakan aplikasi ini. \\
$\mathbf{3}$ & Aplikasi ini mudahdigunakan. \\
$\mathbf{4}$ & Saya berjaya menggunakan aplikasi ini tanpa bantuan orang lain. \\
$\mathbf{5}$ & Aplikasi ini berfungsi dengan baik. \\
$\mathbf{6}$ & Saya suka menggunakan aplikasi ini. \\
$\mathbf{7}$ & Saya fahamarahan yang digunakan dalam aplikasi ini. \\
$\mathbf{8}$ & Saya seronokapabila menggunakan aplikasi ini. \\
$\mathbf{9}$ & Aplikasi ini membantu saya dalam mempelajari Bahasa Melayu dengan baik. \\
$\mathbf{1 0}$ & Saya berjaya menggunakan aplikasi ini tanpasebarangmasalah. \\
\hline
\end{tabular}

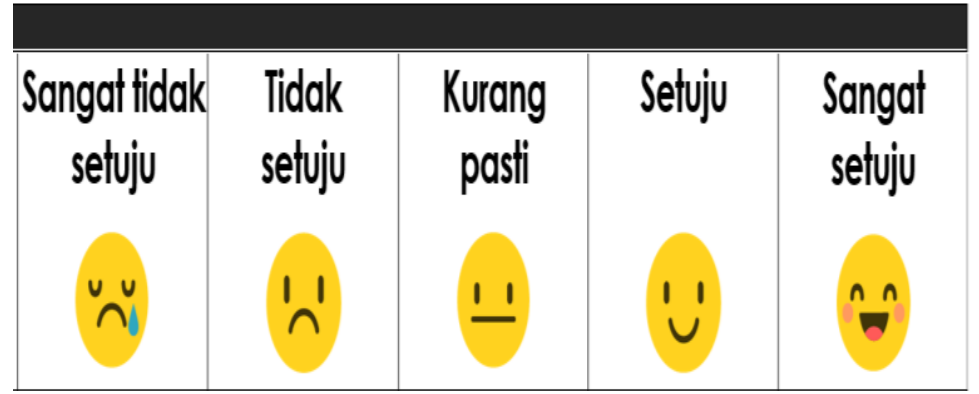

Figure 2.Smileyometer scales

\subsection{Again-Again Table}

According to Mendez et al. (2014)to validate user acceptance for measuring user satisfaction human emotion has to be considered. The relationship between emotion and interactive systems can be measured using three activities namely identifying the relationship, establishing the metric to assess the emotion, and finally interpretand analyse the result (Méndez et al., 2014). The Again-Again tableintroduced by Read (2008) is used in this study as one of the self-reporting techniques for children. The Again-again table is used to measure engagement on something that is fun to do again(Tommy et al., 2019). Thus, the students were asked to rate each of the activitiesin Disleksia Belajarby showing the mobile app interface screenshotsto the students and asked whether they willing to play again (refers Fig. 3). They could answer by usingthe Smileyometer witha 3-point Likert scale either 'Yes', 'Maybe' or 'No'. Each of the activities is calculated based on the frequency of the scales.

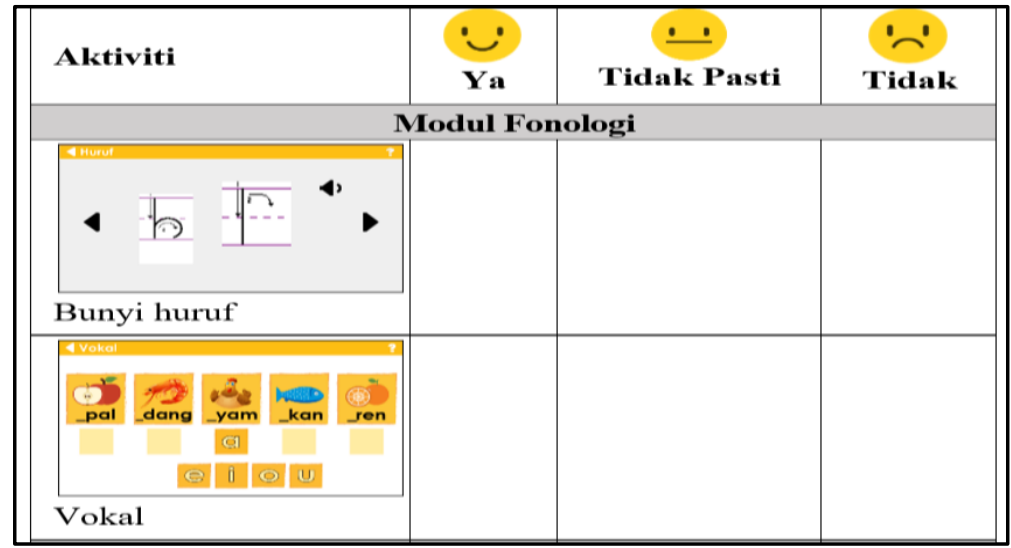

Figure 3.The Again-again table 


\section{The Evaluation}

The evaluation took place in a learning centre at Dyslexia Association Malaysia (DAM) with a total of 12 students participate aged 7 to 12 years old. The participants are mixed with seven males and five females with different levels of dyslexia difficulties. They participated voluntarily with their parent's consent. The instruments of evaluation consist of Disleksia Belajar mobile app, SUS questionnaire, Again-again table, and observation checklists. The session started with a self-introduction to make the student comfortable. Next, the facilitator gave a short briefing to each of the students regarding the activity involved and what they were required to do. The students were given approximately 30 minutes to use the mobile app(refers Fig. 4). However, they could request to end the session at any time if they decided to stop. There were two observers assigned to observe the student's behaviours and make a record in the observation checklist. At the end of the session, the students were given a SUS questionnaire and Again-again table to be completed.
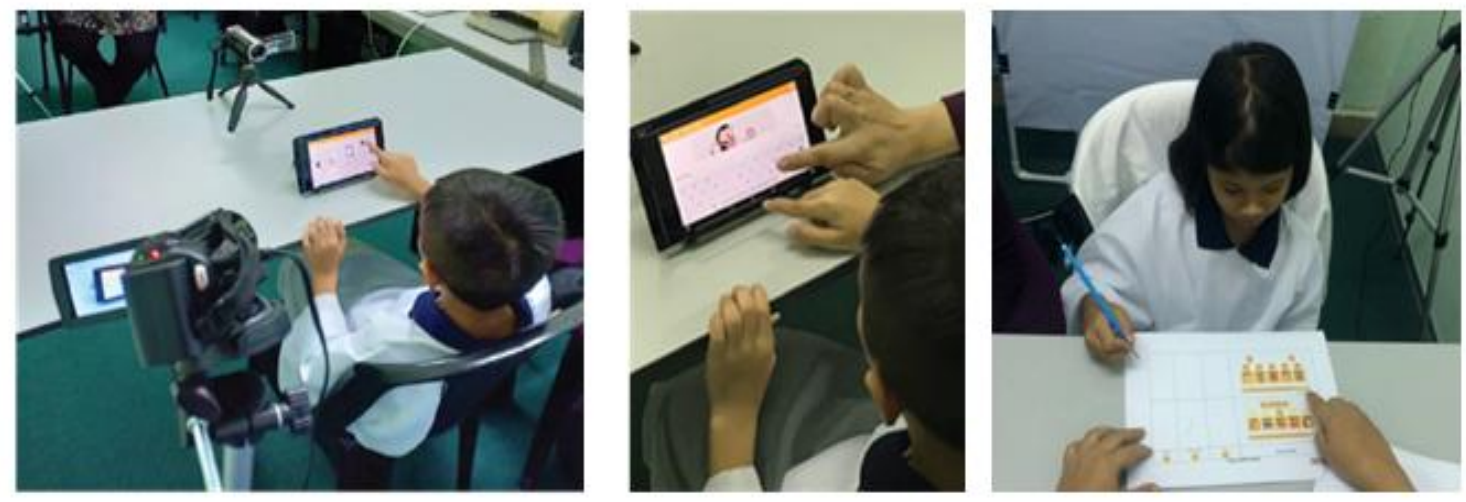

Figure 4.The EvaluationSession

\section{Results and Discussion}

According to Lewis (2018), the minimum accepted average score for SUS is $68 \%$ which indicates that the app is accepted but needs modification. The average score for Disleksia Belajar is $78.3 \%$ that reflected the students with dyslexia perceived the app is acceptable usable. The SUS questions are rated mostly with Agree and Strongly Agree by the students (refers Fig. 5). As for Q1 on frequently using the app, two students rated Disagree and Strongly Disagree as they feel playing the educational games frequently could be boring. Nevertheless, most students wanted to use the app despite the lack of content due to the prototype version. Most of the students feel the app is simple (refer Q2) and easy to use (refer Q3). However, some of the students indicate they are unsure of using the app without the teacher's help. This is due to the fact some of the questions are considered difficult for them. However, in large the students found they could learn by themselves while using Disleksia Belajar. This is a positive condition where it could minimises frustration, low self-esteem, and embarrassment when playing individually.

The results of the Again-again table show the students Agree to play all the modules again in Disleksia Belajar mobile app (refers Fig. 6). They mentioned that the app interface has great colours combination and easy to interact with. This proves the aesthetic visual has a positive effect on students' engagement and increases student's performance (Thielsch et al., 2019). In terms of the cognitive complexity level, it also affects the students whether they are willing to play again. For example, most of the students are confident and willing to play again the activity in the phonology module. While some students have rated Not Sure or No for the spelling, reading, and writing modules, and these students are at the beginner level. The students at the intermediate level do not have a problem in answering the exercises in phonology, spelling, and reading modules but found some difficulty in the writing module. Only students at the advanced level are interested and willing to play again the writing module especially the comprehension exercise. This indicated as the cognitive complexity of the language increases it has slightly influenced the students' interest. Even though the contents were designed in an interactive way as the other modules. 


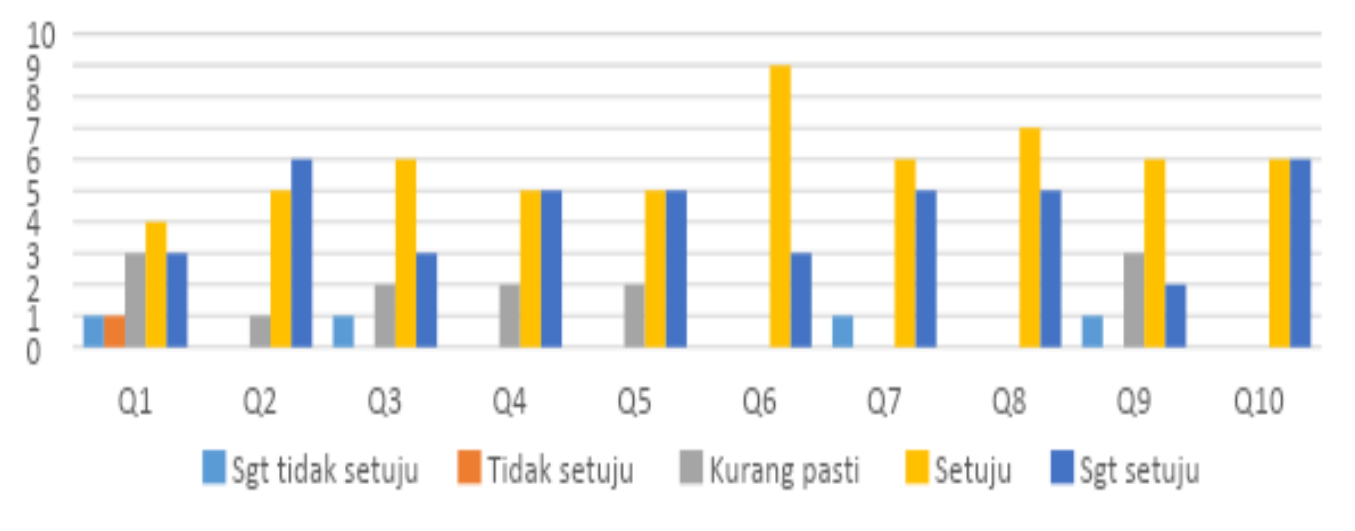

Figure 5.SUS Evaluation Result for Disleksia Belajar

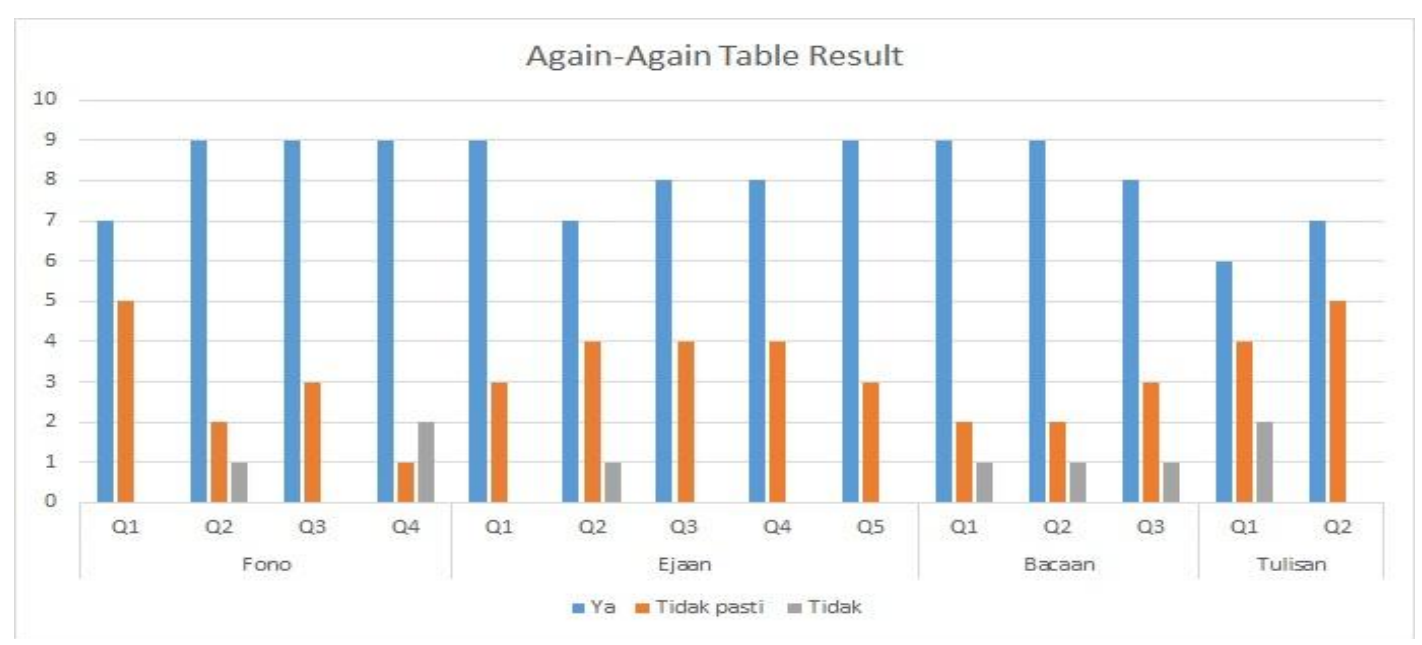

Figure 6.Evaluation on Again-Again Table

\section{Conclusion}

In this paper, we present the evaluation of usability and engagement for Disleksia Belajar a mobile app to learn the Malay language for dyslexic students in junior school. Based on the results show the promising prospects of mobile learning holds in such contexts. The results from both SUS and Again-again table show a has positive effect towards the students learning experience with $78.3 \%$ of usability and higher willingness to play again. Most important the findings contribute towards understanding and improvement for the future development of mobile learning apps to support struggling learners just as students with dyslexia. As for future work, we will conduct more studies to evaluate the reliability and validity to obtain more significant results.

\section{Acknowledgment}

Special thanks to president of Dyslexia Association (DAM), dyslexia expert panel, coordinator, teachers, parents, and students for great assistance in this research. We would also like to thank the university's ethics committee who approved our application to conduct this study and Ministry of Higher Education (MOHE) under Fundamental Research Grant Scheme (FRGS) Grant, cost centre: 5540289 for the research funding.

\section{References}

1. Admodisastro, N., Chan, K.F., Hassan, S., Kamaruddin, A., Manshor N., and Mohd Ali, N. (2018). Disleksia Belajar: Mobile App for Dyslexic Children to Learn the Malay Language, in the Proc. in the Invention, Innovation \& Design on e-learning in IUCEL, CTL \& IIUM, Malaysia.

2. Ahmad, S. Z., \&Mutalib, A. A. (2015). Preliminary study: An investigation on learning assistance requirement among low achievers in primary schools. International Journal of Computer Applications, 114(2), 975-8887. https://doi.org/10.5120/19954-1783

3. Alden, S., \& Pollock, V. L. (2011). Dyslexia and the Studio: Bridging the Gap between Theory and Practice. International Journal of Art \& Design Education, 30(1), 81-89. 
4. Alias, N. A., \& Dahlan, A. (2015). Enduring Difficulties: The Challenges of Mothers in Raising Children with Dyslexia. Procedia - Social and Behavioral Sciences, 202(December 2014), 107-114. https://doi.org/10.1016/j.sbspro.2015.08.213

5. ChePa, N., Bakar, N.A.A., Hussain, A., Hibadullah, C.F. (2019). The influence of rewards on games flow, challenge, and its effects towards the engagement of Malaysian digital traditional games. Baghdad Science Journal, 16 (2), pp. 534-542.

6. Daud, S. M., \& Abas, H. (2013, December). 'Dyslexia Baca'Mobile App--The Learning Ecosystem for Dyslexic Children'. In Proc. Int. Conf. on Adv. Comp. Sc. Apps. \& Tech. IEEE.documents/about-mdanderson/about-us/facts-and-history/quick-facts.pdf

7. Dyslexia International (2017). Better Training, Better Teaching. Retr. from https://www.dyslexiainternational.org/wp-content/uploads/2016/04/DI-Duke-Report-final-4-29-14.pdf

8. GlobalStats (2020). Mobile Operating System Market Share Malaysia. Retrieved from https://gs.statcounter.com/os-market-share/mobile/malaysia.

9. Hoien, T., \& Lundberg, I. (2000). Dyslexia: From Theory to Intervention. Springer Science+Business Media Dordrecht. https://doi.org/10.1007/978-94-017-1329-0

10. Hussain, A., Omar, A.M. (2020). Usability evaluation model for mobile visually impaired applications. International Journal of Interactive Mobile Technologies, 14 (5), pp. 95-107.

11. Husni, H., \& Jamaludin, Z. (2015). BacaMAX: Addressing visual deficit to facilitate reading for dyslexic children. ARPN Journal of Engineering and Applied Sciences.

12. Kaya, A., Ozturk, R., \&AltinGumussoy, C. (2019). Usability Measurement of Mobile Applications with System Usability Scale (SUS). In Industrial Engineering in the Big Data Era. Lecture Notes in Management and Industrial Engineering (pp. 389-400).

13. Lyon, G. R., Shaywitz, S. E., \&Shaywitz, B. A. (2003). Defining Dyslexia, Comorbidity, Teachers' Knowledge of Language \& Reading. In Annals of Dyslexia, 53(1), pp. 1-14.

14. Madeira, J., Silva, C., Marcelino, L., \& Ferreira, P. (2015). Assistive mobile applications for dyslexia. Procedia computer science, 64, 417-424.

15. Méndez, A. Y. A., Ordóñez, C. A. C., Saltiveri, A. G., \&Huitr, J. A. S. (2014). Evaluating interactive systems from an emotional perspective. Revista Científica Guillermo de Ockham, 12(1), 43-49. http://www.redalyc.org/articulo.oa?id=105332478005

16. Ministry of Education. (2018). Quick Facts 2018. Retrieved from https://www.mdanderson.org/

17. Ndombo, D. M., Ojo, S., \&Osunmakinde, I. O. (2013). An intelligent integrative assistive system for dyslexic learners. Journal of Assistive Technologies.

18. Nganji, J. T., \&Nggada, S. H. (2011). Disability-aware software engineering for improved system accessibility and usability. Int. J. of Software Engineering and Its Applications, 5(3), 47-62.

19. Rahim, S. K. N. A., Nasrudin, N. H., Azmi, A. Z., Mohamed, Z., \& Abdullah, I. I. B. (2018). Designing Mobile Application for Dyslexia in Reading Disorder Problem. International Journal of Academic Research in Business and Social Sciences, 8(1), 628-646.

20. Rajapakse, S., Polwattage, D., Guruge, U., Jayathilaka, I., Edirisinghe, T., \&Thelijjagoda, S. (2018). ALEXZA: A Mobile Application for Dyslexics Utilizing Artificial Intelligence and Machine Learning Concepts. In Proc. 3rd Int. Conf. on Information Tech. Research, 1-6.

21. Read, J. C. (2008). Validating the Fun Toolkit: an instrument for measuring children's opinions of technology. Cognition, Technology \& Work, 10(2), 119-128.

22. Sauro, J., \& Lewis, J. R. (2011). When designing usability questionnaires, does it hurt to be positive?. In Proc. of the SIGCHI Conf. on Human Factors in Comp. Systems, 2215-2224.

23. Tommy, C. A., Minoi, J. L., \& Sian, C. S. (2019). Assessing Fun and Engagement in Mobile Applications for Children with Speech Delay. Applied Mechanics and Materials, 892, 79-87 